\title{
Silk Way as a system of favorable cooperation of enterprises of China and Russia
}

\author{
Ekaterina Pogrebinskaya ${ }^{1}$, Xiao Chen $^{2}$ \\ ${ }^{1}$ Doctor of Economic Sciences, Professor; Department of Economics and Business, Bauman Moscow \\ State Technical University, Moscow; \\ ${ }^{2}$ postgraduate, Department of Economics and Business, Bauman Moscow State Technical University, \\ Moscow.
}

\begin{abstract}
Understanding the current investment situation of Chinese enterprises along the "Silk Road Economic Belt" is the premise of making a scientific investment model decision. In consideration of the consistency and availability of statistical data, this paper describes the relevant investment situation based on the statistical bulletin of China's foreign direct investment issued by the Ministry of Commerce and the official investment cooperation data of countries along the Silk Road Economic Belt.
\end{abstract}

Keywords: Chinese enterprises, "Silk Road Economic Belt", foreign direct investment.

\section{Introduction}

The Silk Road economic belt begins with China in the east and connects Europe in the west. It radiates more than 40 countries along the northern, middle and southern lines, connecting almost 3 billion people, and becomes an economic corridor with a huge market scale and development potential. All three lines of the Silk Road Economic Belt start from China, the northern line mainly passes through Russia and other countries of Eastern Europe, the middle line passes through Kazakhstan and other countries of Central Asia, and finally connects to Europe; the southern line passes through Afghanistan, Iran and other countries of West Asia and the Middle East and finally enters North Africa. From 2015 to 2018, the total volume of trade between China and countries along the Belt and road amounted to about 27.4 trillion yuan, with an increase higher than the global average; direct investment by Chinese enterprises in the non-financial sectors in countries along the Belt and road exceeded 56.21 billion US dollars; and recently signed contracts for projects with foreign contracts in countries along the Belt and road reached 449.25 billion US dollars [6].

\section{The purpose of research}

This article analyzes in detail the general situation and regional distribution of investments of Chinese enterprises along the Silk Road Economic Belt. It has been established that the total investment of Chinese enterprises in countries along the Silk Road Economic Belt is growing steadily, and the scope of investment is constantly expanding, 
which leads to the development and construction of countries along the lines of the Great Driving Force.

\section{Results of research}

\section{Distribution of investments in Europe}

This paper uses Russia, Poland, the Czech Republic, Hungary, Slovakia, Romania, Ukraine, Slovenia, Lithuania, Belarus, Bulgaria, Serbia, Croatia, Estonia, Latvia, Bosnia and Herzegovina, Macedonia Albania, Moldova, and Montenegro, as well as European countries along Silk Road Economic Belt, which came to test the investment of Chinese enterprises. Due to the lack of some official statistics, this document finally selects nine countries, namely: Russia, Poland, Czech Republic, Hungary, Romania, Ukraine, Belarus, Bulgaria, and Serbia, to study the investment situation of Chinese enterprises (Table 1).

Table 1. Foreign direct investment of Chinese enterprises in European countries along the Silk Road Economic Belt at the end of the year

\begin{tabular}{|c|c|c|c|c|c|c|}
\hline \multirow{2}{*}{ Country } & \multicolumn{5}{|c|}{ The volume of investments by years, in 10000 US dollars } \\
\cline { 2 - 7 } & 2013 & 2014 & 2015 & 2016 & 2017 & 2018 \\
\hline Russia & 376.364 & 488.849 & 758.161 & 869.463 & 1.401 .963 & 1.297 .951 \\
\hline Poland & 20.126 & 20.811 & 25.704 & 32.935 & 35.211 & 32.132 \\
\hline Czech & 6.683 & 20.245 & 20.468 & 24.269 & 22.431 & 22.777 \\
\hline Hungary & 47.535 & 50.741 & 53.235 & 55.635 & 57.111 & 31.370 \\
\hline Romania & 12.583 & 16.109 & 14.513 & 19.137 & 36.480 & 39.150 \\
\hline Ukraine & 2.929 & 3.314 & 5.198 & 6.341 & 6.890 & 6.671 \\
\hline Belarus & 2.907 & 7.747 & 11.590 & 25.752 & 47.589 & 49.793 \\
\hline Bulgaria & 7.256 & 12.674 & 14.985 & 17.027 & 23.597 & 16.607 \\
\hline Serbia & 505 & 647 & 1.854 & 2.971 & 4.979 & 8.268 \\
\hline Total investment & 476.888 & 621.137 & 905.708 & 1.053 .530 & 1.636 .251 & 1.504 .719 \\
\hline
\end{tabular}

Europe is the end zone of the northern and central lines of the Silk Road Economic Belt. Among European countries, Russia is the main country for investment by Chinese enterprises. According to the table, at the end of 2018, the share of direct investment by Chinese enterprises in Russia amounted to $86 \%$ of European countries along the line. In 2017, the growth rate of direct investment by Chinese enterprises in Russia year on year reached $61.2 \%$. Chinese enterprises are increasingly investing in agriculture, energy, transportation, and other industries in Europe. China plans to invest 10 billion US dollars in Europe along the line to support the construction of regional roads, ports, industrial parks, power plants, fiber optic networks, and transnational channels, providing new development opportunities for European countries along the line.

\section{Distribution of investments in Central Asia}

In this work, Kazakhstan, Uzbekistan, Turkmenistan, Kyrgyzstan, and Tajikistan are used along the Silk Road Economic Belt as countries of Central Asia to study the investment of Chinese enterprises (Table 2).

Table 2. Foreign direct investment by Chinese enterprises in Central Asia along the Silk Road Economic Belt at the end of the year

\begin{tabular}{|c|c|c|c|c|c|c|}
\hline \multirow{2}{*}{ Country } & \multicolumn{5}{|c|}{ The volume of investments by years, in 10000 US dollars } \\
\cline { 2 - 7 } & 2013 & 2014 & 2015 & 2016 & 2017 & 2018 \\
\hline Kazakhstan & 285.845 & 625.139 & 695.669 & 754.107 & 509.546 & 543.227 \\
\hline Uzbekistan & 15.647 & 14.618 & 19.782 & 39.209 & 88.204 & 105.771 \\
\hline Turkmenistan & 27.648 & 28.777 & 25.323 & 44.760 & 13.304 & 24.908 \\
\hline
\end{tabular}




\begin{tabular}{|c|c|c|c|c|c|c|}
\hline \multirow{2}{*}{ Country } & \multicolumn{5}{|c|}{ The volume of investments by years, in 10000 US dollars } \\
\cline { 2 - 7 } & 2013 & 2014 & 2015 & 2016 & 2017 & 2018 \\
\hline Kyrgyzstan & 52.505 & 66.219 & 88.582 & 98.419 & 107.059 & 123.782 \\
\hline Tajikistan & 21.674 & 47.612 & 59.941 & 72.896 & 90.909 & 116.703 \\
\hline Total investments & 403.319 & 782.365 & 889.297 & 1.009 .391 & 809.022 & 914.391 \\
\hline
\end{tabular}

Central Asia is the main zone of the Silk Road economic belt. Among the five countries of Central Asia, although the investments of Chinese enterprises in Kazakhstan fluctuate greatly, their investment is much larger than in the other four countries. The table shows that at the end of the year, the volume of FDI of Chinese enterprises in Central Asia shows an obvious upward trend in fluctuations. At the end of 2016, Chinese FDI in five Central Asian countries exceeded 10 billion US dollars. Energy and non-ferrous metals are the main areas of investment of Chinese enterprises in Central Asia. In terms of cooperation projects, the gas pipeline in Central Asia, the first tunnel in Central Asia and several projects in the field of roads, railways, bridges, and tunnels undertaken by China in five countries of Central Asia are the results of enhanced practical cooperation between China and the countries of Central Asia in the framework of the "Silk Road Economic Belt".

\section{Distribution of investments in West Asia and North Africa}

This paper uses Afghanistan, Turkey, Iran, Iraq, Jordan, Qatar, Saudi Arabia, the United Arab Emirates, Yemen, Egypt, Lebanon, Israel, Kuwait, Oman, Bahrain, Azerbaijan, Georgia, Armenia, Syria, Palestine, as a country in West Asia and North Africa along the Silk Road Economic Belt, which came to test the investment of Chinese enterprises. Due to the lack of some official statistics, this document finally selects ten countries, including Afghanistan, Turkey, Iran, Iraq, Qatar, Saudi Arabia, the United Arab Emirates, Egypt, Israel, and Georgia, to study the investment situation of Chinese enterprises (Table 3).

Table 3. Foreign direct investment by Chinese enterprises in countries in West Asia and North Africa along the Silk Road Economic Belt at the end of the year

\begin{tabular}{|c|c|c|c|c|c|c|}
\hline \multirow{2}{*}{ Country } & \multicolumn{5}{|c|}{ The volume of investments by years, in 10000 US dollars } \\
\cline { 2 - 7 } & 2013 & 2014 & 2015 & 2016 & 2017 & 2018 \\
\hline Afghanistan & 46.513 & 48.274 & 48.742 & 51.849 & 41.993 & 44.050 \\
\hline The United Arab Emirates & 117.450 & 133.678 & 151.457 & 233.345 & 460.284 & 488.830 \\
\hline Turkey & 40.648 & 50.251 & 64.231 & 88.181 & 132.884 & 106.138 \\
\hline Iran & 135.156 & 207.046 & 285.120 & 348.415 & 294.919 & 333.081 \\
\hline Iraq & 60.591 & 75.432 & 31.706 & 37.584 & 38.812 & 55.781 \\
\hline Qatar & 13.018 & 22.066 & 25.402 & 35.387 & 44.993 & 102.565 \\
\hline Saudi Arabia & 88.314 & 120.586 & 174.706 & 198.743 & 243.439 & 260.729 \\
\hline Egypt & 40.317 & 45.919 & 51.113 & 65.711 & 66.315 & 88.891 \\
\hline Israel & 2.388 & 3.846 & 3.405 & 8.665 & 31.718 & 422.988 \\
\hline Georgia & 10.935 & 17.808 & 33.075 & 54.564 & 53.375 & 55.023 \\
\hline Total investment & 555.330 & 724.906 & 868.957 & 1.122 .444 & 1.408 .732 & 1.958 .076 \\
\hline
\end{tabular}

The table shows that Chinese enterprises invest more in Iran, Saudi Arabia, and the United Arab Emirates among the countries of West Asia and North Africa that are part of the Silk Road Economic Belt, as well as investments in most countries of the region, also increasing every year. In 2016, it reached the threshold of $\$ 20$ billion. Chinese companies invest much more in the energy sector of West Asia and North Africa than in other sectors. West Asia and North Africa are the richest oil regions in the world. With the implementation of the Silk Road Economic Belt initiative and the growing demand for infrastructure in West Asia and North Africa in recent years, investments by Chinese enterprises in transport and other areas in the region will also enter a period of rapid growth. 


\section{Conclusion}

The contribution of Chinese enterprises to the Silk Road Economic Belt mainly includes:

- Promoting further integration and development of trade and investment activities between countries along the Silk Road Economic Belt, expanded the countries' trade fields along the belt, optimized the trade structure and updated the trade regime, and developed new forms of business, such as cross-border e-commerce and modern trade in services;

- Speeding up the process of investment facilitation, removed investment barriers and made an appropriate contribution to negotiations on bilateral investment protection agreements and agreements to avoid double taxation, as well as protecting the legitimate rights and interests of investors;

- At the same time, the transparency of technical trade measures, the level of liberalization and simplification of trade procedures, and also helps to increase the level and degree of openness between countries and regions in the region

\section{References}

1. Jiang Guanhong and Jiang Dianchun Greenfield investment or cross-border: the choice of FDI mode for Chinese enterprises World economy, 2017 (7): 126-146

2. Nunnenkamp, P., and M. S. Andres. Ownership Choices of Indian Direct Investment: Do FDI Determinants Differ between Joint Ventures and Wholly Owned Subsidiaries [J]. South Asian Journal of Macroeconomics and Public Finance, 2014, 3 (1) : 39-78.

3. Li Guoxue Institutional constraints and FDI patterns [J]. International economic review, 2013 (1): 160-172.

4. Ramasamy, B. Yeung, M. \&Laforet, S. China's Outward Foreign Direct Investment: Location Choice and Firm Ownership[J], Journal of World Business, 2012(4): 17-25.

5. Cui, L., and F. Jiang. State Ownership Effect on Firms'FDI Ownership Decisions under Institutional Pressure: A Study of Chinese Outward-Investing Firms[J]. Journal of International Business Studies, 2012, 43 (3) : 264-284.

Electronic editions:

6. Ministry of Finance of China // Financial Sector [Electronic resource]. Access mode: http://www.mof.gov.cn/index.htm/ (accessed date 11/10/2019). 